\title{
Er:yag Laser assisted Endodontic Surgery in the Era of New Antithrombotic Treatments
}

Sharonit Sahar-Helft ${ }^{* 1}$, Adam Stabholtz ${ }^{1}$, David Polak ${ }^{2}$ and Mordechai Findler ${ }^{3}$

${ }^{1}$ Department of Endodontics, The Hebrew University-Hadassah School of Medicine, Jerusalem, Israel

${ }^{2}$ Department of Periodontics, The Hebrew University-Hadassah School of Medicine, Jerusalem, Israel

${ }^{3}$ Department of Oral Medicine, The Hebrew University-Hadassah School of Medicine, Jerusalem, Israel

*Corresponding author: Sharonit Sahar-Helft, Department of Endodontics, The Hebrew University-Hadassah School of Medicine, Jerusalem, Israel, Tel: +972-52-2686553; E-mail: helft1@bezeqint.net

Received date: Aug 30, 2016; Accepted date: Sep 27, 2016; Published date: Sep 30, 2016

Copyright: (c) 2016 Sahar-Helft S et al. This is an open-access article distributed under the terms of the Creative Commons Attribution License, which permits unrestricted use, distribution, and reproduction in any medium, provided the original author and source are credited.

\begin{abstract}
Background and Objective: The effectiveness of lasers and their use in many fields of dentistry have been reported. To our knowledge, lasers have not been employed to prevent operative bleeding and maintain a sterile surgical field in patients treated with antithrombotics. Furthermore, new generation anticoagulant and antiplatelet treatments have led to a significant increase in the number of individuals under antithrombotic medications, leading to increased risk for bleeding during treatment as well as post-operative hematomas and infections. Our aim was to review current surgical protocols and clinical guidelines for the management of patients using antithrombotic during minor oral surgery, and determine whether lasers may offer an advantage in the clinical management of such cases.
\end{abstract}

Methods: A literature search for protocols and clinical guidelines for the management of patients treated with antithrombotic medications and its association with excessive bleeding during minor oral surgery was done. Publications which clear relevance to the topic of the current review were included.

Results: 794 relevant publications were identified, of which 29 were with clinical guidelines and 9 were evidence based studies. Relevant information and guidelines from the publications were extracted and summarized. Furthermore, evidence of bleeding and infection control by laser therapy was reviewed to address the possible advantage of such approach in anti-thrombotic treated patients.

Conclusions: Using lasers during intra-oral surgery seems to be beneficial in patients medicated with antithrombotics. The clinical guidelines indicate that anti-thrombotic treatment should not be interrupted for minor oral surgical procedures.

Keywords: Endodontic surgery; Laser assisted surgery; Antithrombotic treatment; Post-operative bleeding

\section{Introduction}

Laser therapy is used for ablation, vaporization, excision, incision and photothermolysis in surgical and non-surgical treatments in the oral and maxillofacial regions [1]. The rapid development of laser technology and understanding of the interaction between lasers and biological tissues led to introduction of laser therapy in endodontic surgery. Classic indication for endodontic surgery includes failure of nonsurgical re-treatment root canal filling, cases of persistent or refractory intra-canal infection [2] or extraradicular infection [3-6]. Despite the fact that the success rate of endodontic surgery is approximately $94 \%$ [7], recent study by Angiero et al. showed promising results utilizing laser instruments during endodontic surgery [8].

The main two laser technologies which have been tested in endodontic procedures are the Carbon dioxide laser and the erbium YAG laser. Carbon dioxide laser is a $0.6 \mu \mathrm{m}$ wavelength emission and is more suitable for soft tissues management [9]. Erbium YAG laser is a $2.94 \mu \mathrm{m}$ wavelength emission and is mainly suitable for enamel and dentin tissue, and has sterilizing properties in periapical surgery [10]. Er:YAG laser also leads to smoother and cleaner surface without thermal damage during apisectomies [11]. In fact Zhao et al. confirmed the superiority of the Er:YAG laser for apisectomy compared with ultrasonic and rotating-diamond instruments, with less postoperative complaints and improved wound healing [12]. Nevertheless, lasers may also lead to side effects such as thermal damage to periodontal tissues [13]. This however, may be controlled by using the laser in a pulsed emission mode.

Approximately one-third of the patients referred for endodontic treatment are medically compromised [14], with growing numbers as a result of extended life expectancy. Furthermore, better understanding of the impact of arterial and venous thromboses on the pathophysiology of several major diseases has broadened the indications for antithrombotic treatment in the general population [15]. To date common conditions are treated with antithrombotic and include: coronary thrombosis; ischemic stroke; limb gangrene; deep vein thrombosis; pulmonary infarction [16]; Atrial Fibrillation (AF); patients post stroke $[17,18]$; patients with ischemic heart disease following either percutaneous coronary intervention or the placement of stents [19]; patients after coronary artery bypass grafting and heartvalve replacement [20,21]; patients with thrombophilia [22] and those 
with a history of venous thromboembolism [23]. Still, the largest group of patient is those who receive anti-thrombotic medication for primary and secondary prevention of cardiovascular diseases [24]. New anticoagulant medications are also introduced into the market with two oral anticoagulants for the prevention of stroke or systemic embolism in AF which were recently approved by the FDA and more drugs are expected to be considered for approval in the near future.

Anticoagulant medication mechanism of action is based on interference of normal coagulation cascade. Medication which interfere with the tissue factor VIIa complex inhibit the initiation of coagulation, while antiplatelet-aggregation drugs (antiaggregants) decrease platelet aggregation and inhibit thrombus formation in the arterial circulation (where anticoagulants have little effect). These drugs are widely used in primary and secondary prevention of thrombotic cerebrovascular or cardiovascular disease [24].

The antithrombotic treatment may have grave implications mainly regarding bleeding control in any surgical procedure, including endodontic surgery. For these patients, some dental treatments may need to be modified [14]. Accordingly, clinical risk assessment during ambulatory dental treatment plan should include evaluation of the possibility of exaggerated/extensive bleeding [25]. This is extremely important in cases where the treatment plan includes surgical modalities.

\section{Methods}

A search of the literature was undertaken using MEDLINE data base and a manual citation review of the relevant literature from 1980 to 2012. Eligible studies included all systematic reviews or any other kind of reviews that suggested clinical guidelines for oral surgical procedures in anti-thrombotic treated patients. Furthermore, all kind of treatment modalities regarding safe treatment and outcome, such as continuation vs. discontinuation of anti-thrombotic treatment were included as well.

\section{Results and Discussion}

794 studies were found in the initial search. Of these, 765 were excluded since they did not include clinical guidelines. 29 reviews and 9 evidence based clinical guidelines were included in the review [26-33].

Overall, there were five management strategies [27] which be summarized in three treatment combinations: 1) continuation of antithrombotic treatment, 2) partial decrease to complete cessation of treatment and 3) switch therapy (discontinuation of one type of antithrobotic treatment and replacement of the medication with a different kind of medicaiton). Evidence-based clinical guidelines suggest that in patients undergoing minor surgical procedures, there is no need to stop vitamin $\mathrm{K}$ anticoagulant therapy [27] as long as the INR is within therapeutic values. Althernativly, warfarin intake can be discontineoued for 2 to 3 days before surgery. There is no need to change the intake of aspirin or clopidogrel before surgery [34]. Discontinuation of antithrombotic treatment has life threating risks, such as stroke in patients with $\mathrm{AF}$, and stent thrombosis in patients following PCI. As a consequence this approach is not recommended. Also, switch therapy may increase postoperative bleeding and therefore is not recommended as well $[35,36]$.

Nevertheless, dentist should be prepared for excessive bleeding during surgical procedures in patients under anti-thrombotic therapy.
As such, clinician must employ any mean available to prevent such grave side effect. One novel approach is laser therapy. The advantages of using lasers for endodontic surgical treatment includes relatively bloodless field and excellent visibility, high precision in tissue removal, enhanced infection control and elimination of bacteremia, no need for sutures, decreased or absent mechanical tissue trauma, fast tissue healing, reduced post-operative pain and edema as well as reduced scarring and tissue shrinkage [37]. Lasers such as Er:YAG laser show anti-inflammatory properties, the the ability to reduce bacterial infiltration of the resected root after apisectomy and retrograde obturation [38,39]. This features makes laser assisted surgery as a promising candidate for the treatment of choice for endodontic surgery, as well as for all oral surgical procedures in patients using antithrombotic medications.

\section{References}

1. Gáspár L, Szabó G (1990) Manifestation of the advantages and disadvantages of using the CO2 laser in oral surgery. J Clin Laser Med Surg 8: 39-43.

2. Walton RE, Ardjmand K (1992) Histological evaluation of the presence of bacteria in induced periapical lesions in monkeys. J Endod 18: 216-227.

3. Nair PNR (1987) Light and electron microscopic studies of root canal flora and periapical lesions. J Endod 13: 29-39.

4. Sunde PT, Olsen I, Göbel UB, Theegarten D, Winter S, et al. (2003) Fluorescence in situ hybridization (FISH) for direct visualization of bacteria in periapical lesions of asymptomatic root-filled teeth. Microbiology 149: 1095-1102.

5. Sjögren U, Happonen RP, Kahnberg KE, Sundqvist G (1988) Survival of Arachnia propionica in periapical tissue. Int Endod J 21: 277-282.

6. Ricucci D, Siqueira JF (2008) Apical actinomycosis as a continuum of intraradicular and extraradicular infection: case report and critical review on its involvement with treatment failure. J Endod 34: 1124-1129.

7. Setzer FC, Shah SB, Kohli MR, Karabucak B, Kim S (2010) Outcome of endodontic surgery: a meta-analysis of the literature--part 1: Comparison of traditional root-end surgery and endodontic microsurgery. J Endod 36: 1757-1765.

8. Angiero F, Benedicenti S, Signore A, Parker S, Crippa R (2011) Apicoectomies with the erbium laser: a complementary technique for retrograde endodontic treatment. Photomed Laser Surg 29: 845-849.

9. Tuncer I, Ozçakir-Tomruk C, Sencift K, Cöloglu S (2010) Comparison of conventional surgery and $\mathrm{CO} 2$ laser on intraoral soft tissue pathologies and evaluation of the collateral thermal damage. Photomed Laser Surg 28: 75-79.

10. Oliveira RG, Gouw-Soares S, Baldochi SL, Eduardo CP (2004) Scanning electron microscopy (SEM) and optical microscopy: effects of Er:YAG and Nd:YAG lasers on apical seals after apicoectomy and retrofill. Photomed Laser Surg 22: 533-536.

11. Komori T, Yokoyama K, Matsumoto Y, Matsumoto K (1997) Erbium:YAG and holmium:YAG laser root resection of extracted human teeth. J Clin Laser Med Surg 15: 9-13.

12. Zhao XY, Wang SM, Zhang CF (2010) Root resection by Er:YAG laser: a scanning electron microscope study. Hua Xi Kou Qiang Yi Xue Za Zhi 28: 526-528.

13. Kimura Y, Wilder-Smith P, Matsumoto K (2000) Lasers in endodontics: a review. Int Endod J 33: 173-185.

14. Jainkittivong A, Yeh CK, Guest GF, Cottone JA (1995) Evaluation of medical consultations in a predoctoral dental clinic. Oral Surg Oral Med Oral Pathol Oral Radiol Endod 80: 409-413.

15. Guyatt GH, Akel EA, Crowther M, Schunemann HJ, Gutterman DD, et al. (2012) Introduction to the 9th edition: Antithrombotic therapy and prevention of thrombosis, 9th ed. American College of Chest Physicians Evidence-Based Clinical Practice Guidelines. Chest 141: 48S-52S. 
16. Weitz JI (2012) Antiplatelet anticoagulant and fibrinolitic drugs. Harrisson`s principals of internal medicine, 18th ed. Mc Graw Hil Medical, NY. 988.

17. Fuster V, Rydén LE, Cannom DS, Crijns HJ, Curtis AB, et al. (2011) ACCF/AHA/HRS focused updates incorporated into the ACC/AHA/ESC 2006 guidelines for the management of patients with atrial fibrillation: a report of the American College of Cardiology Foundation/American Heart Association Task Force on Practice Guidelines. Circulation 123: e269-367.

18. Lansberg MG, O'Donnell MJ, Khatri P, Lang ES, Nguyen-Huynh MN, et al. (2012) Antithrombotic and thrombolytic therapy for ischemic stroke: antithrombotic therapy and prevention of thrombosis, 9th ed. American College of Chest Physicians Evidence-Based Clinical Practice Guidelines. Chest 141: e601S-636S.

19. Grines CL, Bonow RO, Casey DE Jr, Gardner TJ, Lockhart PB, et al. (2007) Prevention of premature discontinuation of dual antiplatelet therapy in patients with coronary artery stents: a science advisory from the American Heart Association, American College of Cardiology, Society for Cardiovascular Angiography and Interventions, American College of Surgeons, and American Dental Association, with representation from the American College of Physicians. Catheter Cardiovasc Interv 69: 334-340.

20. Kushner FG, Hand M, Smith SC Jr, King SB 3rd, Anderson JL, et al. (2009) 2009 Focused updates: ACC/AHA Guidelines for the Management of Patients With ST-Elevation Myocardial Infarction (updating the 2004 Guideline and 2007 Focused Update) and ACC/AHA/SCAI Guidelines on Percutaneous Coronary Intervention (updating the 2005 Guideline and 2007 Focused Update): a report of the American College of Cardiology Foundation/American Heart Association Task Force on Practice Guidelines. J Am Coll Cardiol 54: 2205-2241.

21. Whitlock RP, Sun JC, Fremes SE, Rubens FF, Teoh KH, et al. (2012) Antithrombotic and thrombolitic therapy for valvular disease: antithrombotic therapy and the prevention of thrombosis, 9th ed. American College of Chest Physicians Evidence-Based Clinical Practice Guidelines. Chest 141: e576S-600S.

22. Bates SM, Greer IA, Middeldorp S, Veenstra DL, Prabulos MA, et al. (2012) VTE, thrombophilia, antithrombotic therapy, and pregnancy: antithrombotic therapy and prevention of thrombosis, 9th ed. American College of Chest Physicians Evidence-Based Clinical Practice Guidelines. Chest 141: e691S-736S.

23. Jaff MR, McMurtry MS, Archer SL, Cushman M, Goldenberg N, et al. (2011) Management of massive and submassive pulmonary embolism, iliofemoral deep vein thrombosis, and chronic thromboembolic pulmonary hypertension: a scientific statement from the American Heart Association. Circulation 123: 1788-1830.

24. Vandvik BPO, Lincoff M, Gore JM, Gutterman DD, Sonnenberg FA, et al (2012) Primary and secondary prevention of cardiovascular disease: antithrombotic therapy and prevention of thrombosis, 9th ed. American College of Chest Physicians Evidence-Based Clinical Practice Guidelines. Chest 141: e637S-668S

25. Chandler-Gutiérrez L, Martínez-Sahuquillo A, Bullón-Fernández P (2004) Evaluation of medical risk in dental practice through using the EMRRH questionnaire. Med Oral 9: 309-320.

26. Douketis JD, Spyropoulos AC, Spencer FA, Mayer M, Jaffer AK, et al. (2012) Perioperative management of antithrombotic therapy Antithrombotic therapy and prevention of thrombosis. 9th ed. American College of Chest Physicians Evidence-Based Clinical Practice Guidelines. Chest141: e326S-350S

27. Aframian DJ, Lalla RV, Peterson DE (2007) Management of dental patients taking common hemostasis-altering medications. Oral Surg Oral Med Oral Pathol Oral Radiol Endod 103: e1-11.

28. Douketis JD, Berger PB, Dunn AS, Jaffer AK, Spyropoulos AC, et al. (2008) The perioperative management of antithrombotic therapy, 8th ed. American College of Chest Physicians Evidence-Based Clinical Practice Guidelines. Chest 133: 299S-339S.

29. Perry DJ, Noakes TJ, Helliwell PS; British Dental Society (2007) Guidelines for the management of patients on oral anticoagulants requiring dental surgery. Br Dent J 203: 389-393.

30. North West Medicines Information center (2007) Surgical management of the primary care dental patient on antiplatelet medication.

31. North west medicine information center (2007) Surgical management of the primary care dental patient on warfarin.

32. Nematullah A, Alabousi A, Blanas N, Douketis JD, Sutherland SE (2009) Dental surgery for patients on anticoagulant therapy with warfarin: a systematic review and meta-analysis. J Can Dent Assoc 75: 41.

33. Spyropoulos AC, Douketis JD (2012) How I treat anticoagulated patients undergoing an elective procedure or surgery. Blood 120: 2954-2962.

34. Lillis T, Ziakas A, Koskinas K, Tsirlis A, Giannoglou G (2011) Safety of dental extractions during uninterrupted single or dual antiplatelet treatment. Am J Cardiol 108: 964-967.

35. Garcia DA, Regan S, Henault LE, Upadhyay A, Baker J, et al. (2008) Risk of thromboembolism with short-term interruption of warfarin therapy. Arch Intern Med 168: 63-69.

36. Elad S, Findler M (2008) Periodontal surgery for patients receiving anticoagulant therapy. Arch Intern Med 168: 1719.

37. Bradley PF (1997) A review of the use of the neodymium YAG laser in oral and maxillofacial surgery. Br J Oral Maxillofac Surg 35: 26-35.

38. Yasuda Y, Kawamorita T, Yamaguchi H, Saito T (2010) Bactericidal effect of Nd:YAG and Er:YAG lasers in experimentally infected curved root canals. Photomed Laser Surg 28: S75-S78.

39. Eldeniz AU, Ozer F, Hadimli HH, Erganis O (2007) Bactericidal efficacy of Er,Cr:YSGG laser irradiation against Enterococcus faecalis compared with $\mathrm{NaOCl}$ irrigation: an ex vivo pilot study. Int Endod J 40: 112-119. 